\title{
Stakeholder theory in perspective
}

\author{
Salma DAMAK-AYADI
}

Associate Teaching and Research Fellow, and

Ph.D student, European Centre for Research in Finance and Management (C.R.E.F.I.G.E.), at Université de Paris IX Dauphine

Place du Maréchal de Lattre de Tassigny

75775 PARIS Cédex 16 FRANCE

E-mail salmadamak@yahoo.fr

\section{Yvon PESQUEUX}

C.N.A.M

Professor and Holder of the "Development of Organisational Systems" Chair

292 rue Saint Martin

75141 PARIS Cédex 03 FRANCE

Tel: + 33 (0)1 40272163

Fax : + 33 (0)1 40272655

E-mail pesqueux@cnam.fr

Site web: www.cnam.fr/lipsor 


\begin{abstract}
Those who use stakeholder theory as a reference are both underlining the correlation between facts and a certain conceptualisation thereof (Section 1) and trying to make the necessary shift from a "panoptic" analysis akin to a panoramic vision of texts and positions (Section 2) to an "in-depth" one geared towards an understanding of their foundations (Section 3). As a "theory of organisations", stakeholder theory helps to nourish a relational model of organisations by revisiting questions about "who" is actually working with (and in) the firm. Stakeholder theory is part of a comprehensive project that views the organisation-group relationship as both a foundation and a norm.
\end{abstract}

\title{
Keywords: business ethics, stakeholder theory
}

\section{Introduction}

Stakeholder theory has become the focal point of a great many debates. It frequently serves as a point of reference in agents' discourses, in their acts and in a host of "management science" studies (and even political analyses). Its current tendency is to impose itself as a point of reference by imitating corporate social responsibility policies, to such an extent that it has taken on the allures of a dominant discourse.

This explains the proliferation of false arguments currently circulating on this subject. The purpose of the present text will be to recall those elements of comprehension that are a requisite in any references to stakeholder theory, and to suggest elements of evaluation. The question we ultimately ask is whether it is because of stakeholder theory's apparent facility that it is so pleasing - even though its false evidence may in fact be masking ambiguities that could lead many analysts astray, whether or not they lend any credence to this school of thought.

This theory constitutes a core issue in "pseudo" disputes today, a state of affairs attesting to the status of "the serious thing" that is the firm, and translating the existence of an American intellectualism in the field of management sciences. Texts derived from such discussions have gone forth and multiplied, filling up our libraries with cross-references and book synopses, and with "reviewers" and alternatively "reviewees" happy to join one or the other of the categories underpinning this construction of "academic capitalism". In truth, the very same criticism can also be made of the present text, even though its ambition is to position the elements needed to "decode" stakeholder theory at a level beyond the evidential one that would appear to be its lot.

The very expression "stakeholder" has become so widespread today that many pundits have forgotten that it first arose in the United States as a liberal reaction (remember that what our American friends call "liberal" is what we would call oppositional) to the primacy being bestowed upon financial value, led by the figure of the shareholder - a primacy that became legitimate during President Reagan's time in office. Here it is worth remembering the operation suggested by P. Ricoeur (1997) in the title of his book devoted to questions of ideology: topia asks questions where ideology legitimises, in which case stakeholder theory plays the role of a utopia. However, P. Ricoeur also warns us against the way in which utopia is coopted by ideology. This is yet another issue we will have to deal with, given stakeholders' presence inside of the old managerial utopia of agonism ${ }^{1}$ i.e., the utopia of refusing to recognise the existence of antagonisms in the firm. Workers, shareholders, we're all in it together!

\footnotetext{
1 The expression "agonism" derives from the term "antagonism" and indicates a lesser degree of opposition. Corresponding to the enemy (antagonism) is the figure of the adversary (agonism). As such, agonism sketches the contours of a society (or of an organisation for our present purposes) in which the quest for consensus has replaced the recognition of conflict.
} 
Note first of all the speed with which this corpus has developed, as witnessed by the proliferation of articles and conferences on this subject. Academic research has reserved a special place for stakeholder theory over the past few years. According to T. Donaldson \& L.E. Preston (1995), more than 100 articles and a dozen books have been devoted to this topic, with most having been published in reviews like Business Ethics Quarterly and Academy \& Management Review. However, when taken out of its American cultural context, the stakeholder concept becomes a relatively vague one. It benefits from an "imperialist" effect relating both to the fact that it belongs to the field of management sciences and also to its American origins. The idea here is management sciences are so indebted to American sources that it might as well accept the stakeholder construct without any further do... Yet culturalist understanding is rich with potential. Stakeholder theory could be construed as existing along the same lines of understanding as those that we inherited from Alexis de Tocqueville (1835), with his vision of American democracy and its "heritage of pious merchants" whose interests can best be seen in the light of their "moral equality". It may also be congruent with the vision that Max Weber described in 1904 when commenting on Benjamin Franklin's 1748 opus, Advice to a Young Tradesman. What we should not forget is the absence of this figure of the Tradesman (or of his more generic version, the Businessman) in Continental Europe, where the Bourgeois was much more of a reference point.

According to S. Mercier (1999), stakeholders are "all of the agents for whom the firm's development and good health are of prime concern". E. R. Freeman (1984) defines them as "any group or individual that can affect or be affected by the realisation of a company's objectives". Ethical considerations are what have driven stakeholder theory's rise, having been deployed as a way of constructing its normative aspect (the idea being that we are all stakeholders).

For T. Donaldson \& L. E. Preston (1995), stakeholders are defined by their legitimate interest in an organisation. This implies that:

- Claimants are groups or persons with legitimate interests; that they are known; and that they have been identified:

- All stakeholder groups' interests have at least a modicum of intrinsic value.

Nowadays (A. Caroll, 1989) we usually distinguish between:

- "Primary" stakeholders, referring to those actors who entertain a direct and contractually determined relationship, as the name indicates, with the company (and who are sometimes still called "contractual" stakeholders).

- "Secondary" stakeholders, combining actors who are situated at the borders of a firm and who may be impacted by its actions without having any contractual connection to it (a group that is still described as "diffuse" sometimes).

Other distinctions exist as well, including between internal stakeholders; "traditional" external ones; and other external ones with the power to influence matters. I. Pelle Culpin offers a further distinction (1998) between institutional stakeholders (those involved in laws, regulations, inter-organisational entities, plus professional organisations that may be specific to a given industry); economic stakeholders (actors operating in the markets of the company in question); and "ethical" stakeholders emanating from ethical and political pressure groups (a group whose figuration may be more difficult to define).

Those who use stakeholder theory as a reference are both underlining the correlation between facts and a certain conceptualisation thereof (Section 1) and trying to make the necessary shift from a "panoptic" analysis akin a panoramic vision of texts and positions (Section 2) to an "in-depth" one geared towards an understanding of their foundations and highlighting its ambiguities (Section 3).

\section{Correlation between facts and conceptualisation}


As indicated by F. Lépineux (2003), stakeholder theory sprang out of a maelstrom of "affairs". In 1967, community groups in the United States invited themselves to an Eastman Kodak AGM against a backdrop of racial tension and mass unemployment amongst Greater Cleveland's black population. In the United States again, consumer organisations invited themselves to a General Motors' 1970 AGM to complain about safety defects on the cars being sold, and to ask other questions about Group social practices. The grilling of GM's Board of Directors received a great deal of media airtime. Both of these "generating facts" attest to the significance that executives in these large companies attached to the "societal" dimension, and to shareholder activism's potential for criticism.

In Great Britain in 1997, several shareholders began to ask questions about the political nature of Shell's relationships with the Nigerian government of the time, thereby highlighting a whole series of human rights and environmental protection issues. This "affair" is considered the starting point for stakeholder governance, i.e., for the emergence of shareholder activism.

\subsection{Stakeholders and corporate governance}

Facts of this ilk (some of which are still imbued with a symbolic dimension) are the forces that gave birth to the shareholder capitalism-stakeholder capitalism debate for which stakeholder theory has been a bedrock (M. Friedman, 1970; M. C. Jensen, 2002). Corporate governance issues highlight any and all relationships that may exist between a firm and its partners. In other words, they have contributed greatly to the development of stakeholder theory's practical aspects.

\subsection{Counting all stakeholders}

The stakeholder issue raises questions about how such parties are to be counted. F. Lépineux (2003) suggests classifying them into different categories of actors: shareholders; internal stakeholders (employees; labour unions focused on issues such as employees' direct and indirect participation [via their pension funds] in the firm's capital structure, and on issues pertaining to union representation and/or to a shareholder activism that can be implemented either working alone or else with other investors who also want to get their resolutions adopted); operational partners (customers; suppliers [including subcontractors]; banks acting as creditors but also as parties that expect stability and solvency; and insurance companies having to contend with classes of risk currently undergoing a substantive and indepth renewal, i.e. "greater" catastrophes related with climatic changes today); the social community (State authorities; specialised organisations like trade unions; Non-Governmental Organisations; and civil society). For this latter category, NGO interventions were what first triggered the current debate. One example is the denunciation of the environmental spoliation being caused by oil, mineral and chemical companies, etc. (air and water pollution, deforestation, toxic waste, etc.). Well-publicised trials by media have progressively mutated into greater collaboration with the companies involved. Modern NGOs unite a host of different entities that can be quite disparate in nature, both in terms of their scope and also as regards their geographic reach (with the largest ones being structured into international networks). Moreover, their areas of competency have expanded from green issues in the 1980s to include human rights now, such as these are conceived of by the "stakeholder" concept using the ethical and political precepts it tries to apply.

\subsection{The ambiguity of "social community" when seen as something "singular" or "plural"}

The American construct of "community" is often mentioned as one of the stakeholders in regards to which firms are supposed to behave responsibly. S. A. Waddock \& M. E. Boyle (1995) noted a shift in focus from relationships geared towards a single (close) community, towards more complex relationships with a multitude of communities that can be both close and more distant. This shift has led to greater reliance on the stakeholder concept. The challenge here is how to define the community in its stakeholder form (B. W. 
Altman, 2000) in such a way as to account for the multiplicity of groups concerned whilst covering whatever they may have in common amongst themselves (as well as the modalities for managing such relationships).

\subsection{Stakeholders' changing action modes}

F. Lépineux tried to classify these relationships in 2003 by distinguishing between:

- The shift from dialogue to partnership (i.e., NGO representatives' presence in decision-making processes and/or the acquisition of shares so as to have the right to question executives at AGMsall portrayed as shareholder activism in full flow); and

- The proliferation of the sorts of instruments of pressure that can be brought to bear within a conflictual context, including suggesting resolutions at AGMs, hijacking a company's communications resources ("right-wrong" websites, counter-advertising, etc.) opinion-shaping campaigns, organising boycotts and lawsuits.

But stakeholder theory is different from a mere classification exercise. As shown by an analysis of the texts comprising this school of thought, it is in fact a plan to rearrange the theory of organisations by incorporating ethical perspectives or, if one prefers, by enhancing said theory.

\section{A "panoptic" analysis of stakeholder theory}

Before suggesting any investigations of the field covered by stakeholder theory, we should remember its postulates:

- An organisation will maintain relationships with several groups that affect or are affected by its decisions (E. R. Freeman, 1984).

- Theory will be dependent on the nature of such relationships because of the way in which the processes involved and the outcomes achieved can affect society and stakeholders.

- Stakeholders' interests have some intrinsic value, but no one interest should be able to dominate all of the others (M.B. Clarkson, 1995; T. Donaldson \& L. E. Preston, 1995).

- Theory is interested in managerial decisions (T. Donaldson \& L. E. Preston, 1995).

In regards to the concept of (corporate social) responsibility, stakeholder theory has two variants:

- The first relates to the empirical nature of responsibility. Theory here is based on the idea that an organisation's interests are the first to be taken into account, and that its subsequent efforts are then "divided" up amongst its various stakeholders in a way reflecting their respective levels of importance. Here information is seen as a crucial element allowing the organisation to "manage" its relationships: at the very least to avoid stakeholder opposition; and where possible to gain their adherence.

- The second relates to the organisation-stakeholders relationship, conceived of here as a social relationship implying the genesis of an organisation's responsibility to its stakeholders. This is a normative approach to responsibility.

The article by T. Donaldson \& L.E. Preston (1995) offers a taxonomy of the different stakeholder theories by placing them into three separate categories. Based on the following elements, this taxonomy has served ever since as a benchmark for this field:

- Firms and managers act with moral perspectives in mind (Category 1, which is normative).

- Achieving results becomes more doable if managers act with moral perspectives in mind (Category 2 , which is empirical and instrumental).

- Organisations and managers behave with specifiable moral perspectives in mind (Category 3, which is empirical and descriptive). 
T. M. Jones \& A. C. Wicks (1999) think that this typology helps to delineate the intellectual areas that are covered by stakeholder theory's two founding schools: the empirical stakeholder theory (based on descriptive and instrumental perspectives); and the normative theory (based on ethics). Hence their suggestion, above and beyond the aforementioned "disputes", of a "convergent" stakeholder theory predicated on the following arguments:

- Postulates: organisations operate publicly in an economic marketplace that can be described as competitive; decisions are taken by professional managers; and behaviours are contingent (on circumstances and contexts).

- Theory focuses on the manager-stakeholder relationship, which is deemed to have moral foundations.

- At the same time, theory is also empirical and normative since it offers practical results, i.e., describable norms.

It remains that this perspective has been criticised as lacking in formal construction or empirically testable variables (T. Donaldson, 1999; L. K. Trevino \& R. W. Gray, 1999)

Another distinction traverses this corpus (R. K. Mitchell et al, 1997) between those who refer to stakeholders as representives of a moral or economic interest (with "diffuse" stakeholders not necessarily entering the equation).

\subsection{Is stakeholder theory empirical in nature ?}

This initial question requires first of all a precise delineation of the framework that surrounds stakeholder theory in its two variants.

\subsubsection{Descriptive stakeholder theory}

This is the thesis that T. Donaldson \& L.E. Preston put forward in 1995. In their opinion, this theory considers that organisation is what one finds at the centre of cooperation and competition situations, each of which possesses its own intrinsic value.

Here the theory is being used to describe (and sometimes to explain) specific characteristics and behaviours, including for example firms' nature (S. N. Brenner \& P. Cochran, 1991), how executives' management of their firms should be conceived of (S.N. Brenner \& E. A. Molander, 1977), how some organisations are actually being managed (W.E. Halal, 1990; M. B. Clarkson, 1991; E .P. Kreiner \& A. Bhambri, 1991), the diffusion of societal information ( A. Ullmann, 1995; I. Pelle Culpin, 1998), the notion of target stakeholders (R. K. Mitchell et al, 1997) and the significance attributed to each stakeholder, something that will vary depending on the phase that a firm has reached in its lifecycle (I. M. Jawahar \& G. L. Mclaughin, 2001).

This descriptive approach only allows for exploratory propositions, however. It does not enable any connection to be made between stakeholder management and traditional business objectives (growth, earnings, etc. ).

\subsubsection{Instrumental stakeholder theory}

Instrumental stakeholder theory was advanced by T. M. Jones in 1995 . The main idea here is that everything else being equal, firms that practice stakeholder management will perform better in profitability, stability, growth, etc. terms. One accepts that "certain" results can be obtained if "certain" behaviours are adopted. In other words, the instrumental theory is a contingent one (meaning that it involves reliance on certain types of behaviour ). 
Several recent studies have referred to the instrumental theory implicitly or explicitly by using conventional statistical methodologies focused on:

- The relationship between the pressure that stakeholders can bring to bear and the way in which strategy is formulated (G. Weaver et al., 1999),

- The relationship between social and financial performance (P. L. Cochran \& R. A. Wood, 1984; B. Cornell \& A. C. Shapiro, 1987; S. L. Barton et al., 1989; G. B. Mc Guine et al., 1988; L. E. Preston \& H. J. Sapienza, 1990; L. E. Preston et al., 1991).

Due to the diverse nature of the outcomes obtained, however, no clear relationship in one direction or the other can be affirmed.

\subsection{Is stakeholder theory normative in nature?}

T. Donaldson \& L.E. Preston (1995) also stress stakeholder theory's normative bases. In their opinion, this perspective is distinct from the functionalism found in empirical theory. Instead of compiling data and using ad hoc quantitative methods to test hypotheses, the focus here is on normative outcomes, hence on specifying the moral obligations found beneath stakeholders' positions. What the various approaches of this kind have in common is the fact that they treat stakeholders both as an end and also as having interests that possess an intrinsic value.

The narrative interpretation also characterises the normative perspective by offering narrative representations of firms' moral behaviour. Here emphasis is placed on the ethical obligations a firm faces, and on how it can satisfy them without denying its interest in achieving economic success. A further goal is that of explaining how it is that the objectives being pursued by the actors themselves (by the stakeholders and by the organisation) can be mutually reinforcing.

Researchers adhering to this school of thought will try to uncover the "best" alternative so as to steer corporate activities in ethically more constructive directions. They aver that individuals will modify the language they use (expressing conceptual schemes through images and metaphors) depending on how they think and act. In other words, actors' underlying representations will influence the individual conceptions via which "reasonable" strategic actions are developed.

Such studies entertain close relationships with the search for paradigms found beneath the interpretative theory of organisations, which affirms that individuals will build and maintain their own organisational realities at the social and symbolic levels.

\subsection{How are the different stakeholder theory approaches related?}

The typology we have just presented can be criticised as being derived from a positivism whereby it is assumed that descriptive theory will tell us how the world really is; that normative theory will prescribe how it should be; and that instrumental theory will indicate the shape we can give to it.

The main points of divergence between the two theoretical perspectives are as follows:

- Stakeholder theory's descriptive side reflects and explains the past, present and future. It tends to generate exploratory and predictive propositions, whereas instrumental precepts try to apprehend the connection between stakeholder approaches and mutually beneficial outcomes such as profitability. The instrumental approach is generally used to explore the relationship between causes (the management of stakeholders) and effects (organisational performance). Normative theory tries to study these relations based on their ethical aspects and philosophical principles. In other words, the instrumental approach is mainly hypothetic al (i.e., to achieve an objective " $X$ " 
one needs to adopt [or not to adopt] principles and practices "Y"), whereas the normative approach is categorical rather than hypothetical (doing or not doing something because it is the right [or wrong] thing). Hence the qualifier of "Kantian capitalism" given to some of its avatars.

- Depending on the point of reference being used, there may be some disagreement about T. Donaldson \& L. E. Preston's typology (1995). In an interpretative perspective, there is nothing automatic about the empiricalnormative distinction (for instance, what is the interpretation based on?). Furthermore, certain "normative" studies affirm that moral behaviour has no need of being justified, since morality possesses its own innate merits. Such studies consider that the biggest contribution of the instrumental theory's habitual variant is that it allows for the prediction of certain forms of moral behaviour will be sanctioned in the end, even though this may not occur in the short or medium term.

- "Narrative" modes seem unable to achieve the status of "good research", even if one does accept that it is possible to derive acceptable theory from narrative representations. After all, how does one distinguish between "good" and "bad" representations given that theoretical representations of this sort spring from their narrators' own imaginary worlds?

- T. M. Jones \& A. C. Wicks (1999) believe that "good" theory must help individuals to lead "better lives" within organisations. The question here is whether one should in fact validate the idea that narrative representations do actually help people to lead "better lives" in the absence of any empirical verification for this proposition.

- The interpretative theory contrasts with attempts to give higher marks to studies that try to create consensual paradigms.

G. R. Weaver and L. K. Trevino (1994) have suggested a hierarchy of interactions between empirical and normative theoretical perspectives based on three different conceptions: parallelism; symbios is; and integration. This perspective is grounded in two main ideas. The first is practical in nature and refers to stylistic and methodological differences amongst different empirical and normative requirements. The second is conceptual and involves theoretical conceptions and hypotheses, mainly as regards human behaviour, which is portrayed as being mechanistic in the empirical approach and autonomous and responsible in the normative one:

- For conceptual and practical reasons, parallelism rejects any connection between the empirical and the normative. In a sense, the only items that the two perspectives have in common are a "certain" interest in "certain" types of behaviour. There is no connection between the two, however. Empirical research is carried out without any reference to philosophical, ethical or religious developments. The opposite holds true as well.

- Symbiosis signifies that the two perspectives (empirical and normative) feed into one another but remain distinct in terms of their theoretical principles, methodologies and hypotheses. A symbiosis principle is conducive to the existence of at least a modicum of agreement in given areas, i.e., in addition to both approaches' interest in the same area of research they also share certain values and explanations. The shared values include the idea that stakeholders' demands do possess some intrinsic merit, and that egotism is to be rejected since it is impossible for an individual or an organisation to serve its own purposes and nothing else. Interest in others is therefore a norm that the two theories share. This theme has been covered in several studies including the debate on corporate social responsibility (T. M. Jones, 1995), the moral debat (A. Konrad, 1982), "Kantian capitalism" (W. M. Evan \& R. E. Freeman, 1983; N. Bowie, 1994), feminist approaches and property (T. Donaldson \& L. E. Preston, 1995) and agents' morality (D. Quinn \& T. M. Jones, 1995). Regarding the compatibility between morality and capitalism, the two aforementioned values do not intimate that acting in one's own interest necessarily constitutes something suspicious. What is suspicious however is the strict search for profit. A "reasonable" consensus exists around the idea that if capitalism is to be in good health it will require a "modicum" of morality. There is only partial agreement on these values, however. Normative theory considers morality as something that "by its very nature" is a given, even though the actual 
source of this morality has long been a topic of heated philosophical debate. Empirical and normative studies also share certain general explanations. T. M. Jones \& A. C. Wicks (1999) believe a consensus exists that it is unlikely that descriptive theory will develop much further in the short run. They also consider economic theories' opportunism hypotheses as being much too simplistic. Elements like irrationality, altruism, generosity, cooperation, trust, honesty, interest in others, etc. are just as typical a characteristic of human behaviour. Lastly, there is widespread conviction that those organisations that focus on stakeholders and behave in a socially responsible manner perform better than those that only seek financial gain.

- Integration signifies that the two perspectives can be seen as belonging to one and the same theoretical framework; and that they manifest themselves via the importing of concepts (with one approach evoking concepts found in the conceptual framework of the other), theoretical reciprocity (incorporation of both empirical and normative theory in one and the same study) and theoretical unity (rejection of distinctions between the empirical and the normative at the methodological and meta-theoretical levels). Authors from this school consider that all theory is incomplete when it is exclusively empirical or normative in nature. Methodologies and hypotheses can be combined if such an action is grounded in a partial consensus driven by whatever points are shared by the different components involved. Integration leads to a recognition of empirical theory's normative foundations (principles of mutual trust and cooperation), thereby increasing their credibility. It remains that integration has been sharply criticised by E. R. Freeman (1999) as being incapable of avoiding the deontologism-consequentialism debate.

Stakeholder theory also contains ambiguities that an in-depth exam should be able to reveal..

\section{An in-depth analysis of stakeholder theory}

Despite its ostensible facility and "false" evidences, stakeholder theory was born in correlation to the "liberal moment" of the 1980s and is therefore rooted in the developments of the philosophical school of thought that we can call "neo-liberal". It is with regards to the various categories that make up this particular school that we can offer the modalities for a comprehensive and "in-depth" analysis, once we have taken all necessary precautions against the "exoticism" that one needs to mention when referring to this particular corpus. Indeed, $\dot{t}$ appears to be entirely unacceptable for an analyst to make any remarks whatsoever regarding stakeholder theory without simultaneously commenting upon its presuppositions, grounded as they are in the pragmatic foundations of this particular school of philosophy. The authors themselves recognise this affiliation (at least T. Donaldson, K. Goodpaster and E. R. Freeman do). Didn't they all used to study philosophy?

R. Phillips, E. R. Freeman \& A. C. Wicks (2003) have been forced to express themselves on the incorrect usages being made of this theory. Amongst other things, they have affirmed that it constitutes an ethical theory of organisations - a point of view to which we will return at the end of our argument, albeit in regards to other elements. The analysis we are pursuing here is based on arguments that are quite different from the ones put forward by these two authors.

This is because the theory is not actually a contractualist one. It is born in American "neo-liberal" philosophical perspectives whose central purpose is to develop a theory of justice. The stakeholder concept can be seen as referring to a communitarian perspective, with the stakeholder thereby helping to define the contours of a group to which actors can belong on a non-exclusionary basis. Indeed, this is what constitutes the theory's wealth and its ambiguity. A citizen can simultaneously be a customer, shareholder, employee and a "diffuse" stakeholder. Analysis of his/her position should be organised in terms of the category (defined by the particular type of search for fairness involved) that is relevant to the specific stakeholder role s/he is playing at a given moment in time. 


\section{1. "False evidence" in stakeholder theory}

The first false evidence in stakeholder theory relates to its ostensibly descriptive status, which may justify using a "Mintzberg complex" (1999) to qualify this theoretical perspective. In much the same way as organisations that used to live "happily" before it came along allegedly suddenly turned into adhocracies or professional bureaucracies, now they are deemed to have become the central foci for stakeholders! In which case it is possible to assert that stakeholder theory is merely a reformulation of the old introductory lesson in corporations and partners, this time around using an ostensibly more "modern" discourse. This viewpoint raises questions about the not always very obvious dichotomy that is said to exist between the theory's descriptive usage (does it create better descriptions?) and its normative usage (are we all stakeholders or else destined to turn into one?). A further usage is supposedly found in the strategy categories. This involves an intermediary expression that one can apply in its vaguest connotation, with the stakeholder reference being seen as something enabling a superior formulation of strategy (or strategic discourse). The idea here is that stakeholder theory serves to reinvigorate functionalism by not answering any questions about what it is that constitutes an organisation's actual foundations. What we would then be dealing with is an organisational metaphor that is ideological in scope. Simplification and incantation would be some of the traits of this construct, which is capable of specifying "friendly" or "enemy" factors at both the conceptual and the "real" levels (this being the place where we uncover one aspect of its embeddedness in pragmaticism).

The second false evidence pertains to the possible merger between stakeholder theory and "the new theories of the firm". C. W. L. Hill \& T. M. Jones (1992) see the former as being generalised throughout the different categories of agency theory, in the sense that they focus mainly on the stakeholder-manager relationship. In this sort of "forced" contractualist perspective, managers are depicted as agents, whereas stakeholders are distinguished from one another on the basis of their importance and power vis-à-vis managers. When reinterpreted thusly, agency relationship involves, in accord with market "mechanisms" and the ingredients comprising its logic, a balancing of interests. E. R. Freeman \& W. M. Evan (1990) integrated stakeholder theory into the transaction cost theory that R. H. Coase (1937) and O. E. Williamson (1985) had developed based on the assertion that managers are there to "manage" contracts with employees, owners, suppliers, customers, communities, etc., with a view towards developing "fair contracts" that should be analysed as the necessary moral precondition before the different parties can commit themselves. Since all parties have an equal right to sign contracts, any group is capable of investing in specific transactions that might affect the other groups, but in so doing the goal should remain that of developing a mode that enables conflict resolution and safeguards the rights of all committed parties. Here the concept of "fairness" becomes a key benchmark since it is based on the normative perspectives that are inherent to human behaviour. T. Donaldson \& L. E. Preston (1995) tried to connect stakeholder theory to property rights theory to justify the idea of getting property rights categories to represent the interests of stakeholders other than shareholders. The main difficulty here is how to connect different stakeholders by means of property rights that have been reduced to their formal dimension, and to do this within a distributive justice perspective. Remember that distributive justice is a key concept in modern neo-liberal philosophy, with its reference to L. C. Becker (1992) and especially J. Rawls (1987). The reference to L. C. Becker seem particularly strange given the fact that many "much more" important philosophies have already dealt with this question. This reference was primarily chosen in an attempt to devise a property theory that can be correlated with stakeholder theory (so that each stakeholder can be allocated legal rights and formal property rights). E. R. Freeman has in fact already validated this stance (1994). C.M. Jensen severely criticised stakeholder theory in this respect, however (2000), when he complained that it does not allow for a sufficiently objective substantiation of a company's mission, and that it provides an excuse for executive opportunism.

It remains that these attempts to connect stakeholder theory to "the new theories of the firm" have stumbled over several postulates and their underlying hypotheses. These include: 
- The market efficiency postulate, since the normative foundation of stakeholders' interests leads to their being recognised as possessing social "depth", in turn disturbing the "purity" of the economic signals being diffused;

- The normative perspective, which is not in tune with the methodological individualism postulate;

- Inter-individual contractualism is replaced by a categories-based contractualism that imbues it with a metaphorical dimension.

The third false evidence relates to the theory's psychological aspect and is part of a drive to refuse egotistical subjects and to accept more reflective ones that are merely expressing a desire that they may have. In referring to a "generic" subject, however, the theory is seeking less of a footing in neo-liberal perspectives (particularly those found in an ultra-liberalism predicated upon the bestowal of radical primacy upon individuals, and therefore on the proliferation of rights that can be valued in a "market"). Instead, it is sinking roots into a civic type of republicanism (belief in the existence of a "common good" that adapts stakeholder interests so they can encompass "civic virtues"; plus a denunciation of deviations like the type of corruption that is caused by a conflict of interests - this being the place where we spill over into governance questions).

The fourth false evidence relates to its sociological aspect. Stakeholder theory features subjects that are "generic" (customers, suppliers, employees, etc.) but which do not constitute social categories. What we should be mostly discussing here is stakeholder theory's contribution to the anthropological conception of organisations that benefits from this genericity. The generic subject that is the subject of the organisation still appears here in his/her daily reality, i.e., in the concrete and peculiar form of "being in situation". As such, stakeholder theory paves the way for kinds of categories where subjects can have two reasons for belonging: one as the fully formed human beings they are; and the other as a specific form thereof. By so doing, stakeholder theory offers a sort of false validation for Cultural Studies that, it should be remembered, advises rethinking about cultures no longer in terms of any culture-nation links but instead in light of the culture-social groups connection (Hoggart, 1973; Hall \& Jefferson, 1975; Willis, 1977; Hall, Jacques, et al., 1990, etc.). Cultural Studies of this ilk currently enjoy a great deal of media-driven success in Business School education and research. The "masses" and the perspectives for understanding them have replaced "class"-oriented reasoning, with stakeholders constituting the figures used to enhance understanding of these "masses" based on a "complex equality" between each of their individual interests.

Of course, with its reference to a roles concept, stakeholder theory does have something to contribute to the sociology of organisations. Along with M. Crozier \& E. Friedberg (1977), it should be remembered that an actor is someone who plays a role in an organisation based both on his/her imaginary world (possibility of identifying with an ideal person or of masking one's personality) and functional aspect (involvement in a specific situation). As such, the stakeholder concept offers the socialisation process a comprehensive perspective whereby it becomes possible to design an idealtype role combining organisational and personal aims. This would also mean being able to imagine stakeholders being brought back into the "old" categories, as analysed by R. Katz \& R.L. Kahn $(1966,1978)$ when they distinguished amongst varying expectations of role, role transmission, role reception and behaviour within a role.

It is also by starting out with this role concept that we can move on to a games concept related to cultural models of society. Here stakeholders are seen as concrete evidence of such "games" socialisation power in which case the stakeholder concept does indeed lie at the heart of the role-game-strategy trilogy - and of the influence concept. After all, influence is what creates a perspective that can be both intentional and interactional. It also creates a duality between substantive rationality (values) and procedural rationality (codifiable behaviours). At the same time, stakeholders are characterised by an erosion of the universalist nature of social contracts. They open the door to a cultural relativism that is connected to each and every one of them. 
We should ako stress, from an ideological point of view, the theory's absorbent characteristics:

- From a descriptive point of view (since it appears to "use up" organisational description due to its exhaustive nature)

- From a normative point of view (since as many stakeholders crop up as are necessary, with "diffuse" ones following in the steps of their "contractual" counterparts)

- From a deterministic point of view (in which case all stakeholders are to be viewed as the structuring agents of an organisation, this being the very expression of their "essence").

- From a theoretical point of view (with stakeholder theory being seen as a parallel to the transaction cost theory that it echoes - and the same applying to the contractualist perspective, even though what we dealing with in the present case is a "pseudo-contract"). The two corpuses benefit, in a multiplicative manner, from their respective outlooks. The moralism found in stakeholder theory combines with the contractualism and economicism found in transaction cost and agency theories (Clarkson, 1995).

- From a justificatory point of view (with philosophy and ethics entering alongside of it into the domain of "affairs").

- From a "spontaneist" point of view (given stakeholders" "indisputable" existence).

Here we are having to contend with the fact that it is relatively easy for many of the theories that one finds in the social science fields to be turned into ideologies (Boudon, 1986). All this requires is: simplification; a semblance of representativity; a vehicle for comprehensive presuppositions; and a sympathetic aspect.

This justifies our questioning the quality or inversely the relative mediocrity of any references to this theory, particularly given the way its legitimacy has developed over time. Built in opposition to the figure of the shareholder, the stakeholder first appeared as a means for preventing the merry-go-around of excessive dividend distribution, before being "co-opted" (as is so often the case with criticisms) to such an extent that stakeholders are now viewed as the expression of a communitarian liberalism that has started to "sag" due to the "spontaneist" nature of its occurrence. Of course, its main ambiguity stems from the fact that "non-stakeholders" are "legitimately" excluded - raising questions as to what society these excluded parties belong to.

Stakeholder theory is neither economic, nor psychological, nor sociological, nor (and this is crucial for anyone interested in "the theory of organisations") psycho-sociological. Ultimately it is ethical, with all the ambiguity and richness that this entails.

\subsection{The ethical foundations of stakeholder theory}

All in all, stakeholder theory raises a number of questions about the actual ethical bases upon which it is based. At the very least, authors in this field agree that it requires some "practical" aspects so that it can be grounded in "applied ethics" from the very outset. Nevertheless, this formal perspective does not resolve all of the questions pertaining to the theory's foundations.

Is stakeholder theory rooted in needs or in desires? This question is a source of ambiguity. We find both aspects with so-called contractual stakeholders (expression of the need for "honest" sourcing from suppliers; the confusion between needs and the desire for honesty from customers; the desire with shareholders for honest gains). On the other hand, neither needs nor desires are capable of accounting for the foundations of the expectations of diffuse stakeholders working to develop "good lives" that they can use as a benchmark. For this group, the goal is to "wake up" at the right time, that is, whenever their "good life" starts to be perturbed by the consequences of a firm's actions.

More generically and above and beyond the duality between needs and desires, we might be able to use the concept of people's interests to ascertain the foundations for stakeholdership. Here stakeholders are 
situated in categories defined by the modern reinterpretation of moral sentiments. Remember the simultaneously ontological and normative perspective by which moral sentiments are characterised. In this vision, honesty is construed as a moral sentiment and is connected to the subject at a fundamental level because of the honest subject's presuppositions and because of the way in which s/he normalises his/her behaviour depending on circumstances. To a certain extent, moral sentiment is situated between reason and emotion: reason because it provides an axiological foundation for behaviour (which can be either "good" or "bad"); and emotion because of its deeply subjective underpinnings. Stakeholder theory is therefore a means for narrating one's "good life" to oneself, against the backdrop of the moral substance of today's economic activities, and from an eudemonistic perspective (based on a conception of happiness) as opposed to a hedonistic one (solely based on desires). In fact, it is at this evel that the theory can be truly described as a "theory of organisations". It is also here that stakeholder theory can be linked to countless organisational narratives (Y. Pesqueux, 2001). The present text will not linger on this question of narratives, but it should be noted that it is in this sense that the stakeholder concept is attached to membership categories as opposed to citizenship ones (M. Walzer, 1998).

Having started out with the theory's ethical foundations, we can now shift to its political consequences and discuss the contours of stakeholder capitalism (creation of value for customers, suppliers, communities, employees... with shareholders and banks only coming at the end of the chain). E.R. Freeman is one of the most fervent defenders of this construct, but also of stakeholder society, a vision that W. Hutton (1999) helped to found. Yet is not true that both these schools raise the question of democracy only after having first embedded it in capitalism, which they construe as a political order? And don't both perspectives lead to a conception of democracy in which it is defined using the stakeholder construct? There is little doubt that these visions constitute a reversion to the contours of ideology, in the "initial" political sense of the term, an ideology whose existence was evoked at the beginning of the present text in regards to the stakeholder concept. In turn, this helps us to talk about how the stakeholder concept has been used to substantiate the political validity of a society that is reticular, i.e., where categories are not treated equivalently but where treatments are differentiated by territory and by institution.

Or else, might it be that stakeholders are the drivers of a new strategic organisational discourse, leading to the formulation of a strategy that is no longer merely responsive but which is in fact proactive in its efforts to create greater value (the initial vision having turned out to be excessively anchored in the short-term)?

\subsection{Stakeholders as a potential foundation for deliberative democracy}

The issues raised by the deliberative democracy construct are relatively subtle ones, since the categories it uses are currently being developed within the confines of representative democracy categories. Of course, this latter system is still being presented as a palliative - although we view it, through the reference to the stakeholder construct, as akin to a fully-fledged democratic structure. Remember first of all the reduced contours that Gutmann \& Thompson (1996) lent to deliberative democracy by depicting it as a situation where forms of politeness are the only things that need to be respected - a stance that disturbingly resembles the codes of conduct that usually prevail in acts of discussion undertaken in the attempt to develop norms. As such, deliberative democracy indicates the significance that has been attributed to reciprocity in such deliberations; to the publicity surrounding announcements of the stances held by the different protagonists (stakeholders whose positions, however extreme, have to be broadcast in the name of some transparency principle); and to the responsibility of the debater towards the community s/he is representing during the debate. To a certain extent, this operates "independently" of the general representativity of this community, much as is the case with stakeholders.

Making references to deliberative democracy means distinguishing between politics construed as a place for reconciling divergent interests and based on the antagonism dimension (polemos) - and politics whose 
purpose is to "establish an order", organise coexistence (polis) and enable actors to live together in a dimension of agonism. The deliberative democracy project is therefore one that is based on a pluralistic order where the transformation of enemies into adversaries constitutes a pre-condition for democracy's existence in society and within firms - this being a society that we can describe as being reticular since it does not imply the equivalent treatment of all parties located on a territory at a given moment in time, be it a geographic territory and/or in the "institutional" sense. Using stakeholder capitalism categorisations, modern societies can be portrayed as reticular since the groups by which they are comprised are said to result from more or less stable relationships that are built upon the expression of preferences, affiliation and interests, and not on a territorial and/or institutional (i.e., citizen-based) type of belonging. This would appear to result from the fact that relationships here are easier to modify and therefore more "plastic" than traditional social stratifications are. It is because of this pluralistic expression of points of view, and due to this innovation-related interplay, that we are given permission to envision stakeholders from a global governance perspective. In this view, multiculturalism is equated to confrontation with a plurality of interests in a world where such a pluralism of positions (and of their underlying values) itself tends to constitute a value.

The deliberative democracy that ensues is simply construed as lack of coercion as regards stakeholders' possibilities for expression. It is important to put this position into perspective when dealing with republicanism traditions and the proliferation of the new political spaces that mark the "liberal moment in time". In any event, due to the implicit primacy being attributed to individual freedom, categories of this sort are destined to "stumble" over equality issues in a society where the possibilities for communication have increased due to the proliferation of information and communications networks.

To explain the ever-greater legitimacy being awarded to deliberative democracy categories, one thing we can do is reproduce arguments that Boblio first formulated in 1987 when discussing modern life's excessive scale, the growing bureaucraticisation of the State apparatus (and of corporate apparatuses, we should hasten to add), the increasing technicity of decision-making and civil society's tendency to become a mass society. The democratic challenge here is how to create compatibility between pluralism and individualism - and, given the connections between the different "flexible" specialisations one finds in society and in organisations that have become reticular in nature, how to act out the increasing significance being attributed to decentralised economic regulations.

"Common good" issues are raised in this reference to democracy, be they representative or deliberative in nature. With the latter, "common good" neither derives from a generalised will nor is it the product of whatever legitimacy may have been attributed to individuals' atomistic nature or to the marketplace. In the different categories found in deliberative democracy, the point of reference is the role attributed to the notion of "merit", when associated with the different stakeholder-specific avatars of the "common good" (Macintyre, 1984). Merit becomes the basis for those constituent commitments that serve to unite members of a given community (Sandel, 1982) around the representation of a "common good" - the idea being that this constitutes a reasonable plan. Here the thought that the common good comprises something "moral" replaces another perspective in which it is viewed as something "political" in the aspects of a complex equality in relation with these different "common goods" (Walzer, 1983). This might explain why some areas are dealt with an inter-stakeholder discourse like sustainable development and global responsibility.

This led to the idea that policies should be designed "in their time", hence that deliberations should be organised in a way that interconnects the members of community. The goal becomes that of establishing a technical democracy as an alternative to a State intervention that is deemed to be excessively "unequivocal". It is within this framework that "technicised" civic virtue can materialise and be used to denounce, observe and enable expression. In short, stakeholder deliberations should be organised in a way 
that allows for the constitution of a civic consciousness without the imposition of any eudemonia. Such an organisation should be positioned between a negative conception of liberty (the absence of coercion) and a positive one (the individual's desire to be his/her own master without such a desire being nothing more than mere individualism). The deliberation's organisation would then enable the formulation of "reasonable interests" within the framework of an effective response to a pluralism in which power, laws and knowledge would be marked by a lack of determination. This would create the possibility that a truly reticular society could take shape, and that modern democracy could designed both with and against the "total" State - paving the way for a deliberative democracy that is freed from the facade and the deforming intermediation of political parties, thus reoccupy ing spaces in political discussion. As a material form, this organisation could constitute an alternative to the forces of persuasion and symbolic violence that come with the exercise of power. It would offer the guarantee of pluralism as a value.

This could also constitute a shared identification framework for both individuals and citizens, based on a rationalist humanist perspective inherited from technical perfectionism broken down into political dimensions. To a certain extent, this would involve organising the techno-ideal conditions of a debate that combines reasonableness and neutralism, with a view towards the expression of a reasonable plurality developed using stakeholders as a reference. Deliberative democracy would lead to the implementation of a "fair effect process" that could connect fairness and a feeling of fairness (in a sort of self-fulfilling prophecy that also takes the discourse's perlocutory effect into account) by using the "convergent lenses" of "differentiated common goods" and thereby leading to yet further justification for the reticular society expression. The organisation of the deliberation would pave the way to a self-government perspective (given that it would constitute one of the enabling conditions thereof).

\section{Conclusion}

As a "theory of organisations", stakeholder theory has helped to found a relational model of the organisation. The relations in question could in fact start to form an organisational "substance", but the perspective would then remain relatively functionalist in nature. Once again, "organisational sciences" are predicated here on the implicit postulate of the following continuum: individual group-community-firmorganisation-institutions-State. After all, a firm is also an organisation. This explains why stakeholder theory is considered a likely way of offering scientific substance to explanation of what institutions are really made out of, since these entities can then be studied by means of organisational concepts. In this way, stakeholder theory leads to the organisation being reified in an ahistorical dimension, an act that reduces their "formal diversity" and diminishes their institutional and political nature.

Let's briefly recall the doubly epistemological dimension of the organisational model (Y. Pesqueux, 2002). This model is based on a "reduction of reality" and on a normative reference - with all of the discursive dimensions associated with these two perspectives and that enable discussions of the model concerned within the lexical field to which it belongs. Here stakeholder theory becomes part of a comprehensive project relating to the organisation-groups relationship and is simultaneously viewed as a foundation ("the essence" of the organisation being born from the relationship with these groups); a norm (so that it is up to the organisation to affirm "perseverance in its being" by managing the its stakeholder relationships); and a theory of action (enabling analyses of organisations' relational strategies, c.f., D. P. Baron, 1995; R. Bucholz et. al., 1994). Its current status in organisations correlates to whatever legitimacy is being bestowed upon the management-by-project idea. The upshot is that stakeholders should give voice to any differences in values that may exist at a given moment in time - in which case the project should fall in phase with stakeholders' federating role.

\section{BIBLIOGRAPHY}


Altman B. W. [2000], "Defining "Community as Stakeholder" and Community Stakeholder Management: A theory Elaboration Study", in Research in stakeholder heory 1997-1998, Clarkson Center for Business Ethics, University of Toronto

Baron D.P. (1995), Business and its Environment, Prentice Hall

Barton S. L., Hill N. C., Sundaran S. [1989], "An empirical Test of stakeholder theory Predictions of Capital Structures", Financial Management, vol. 18, n 1, pp. 36-44

Beauchamp T., Childress J. [1994], Principles of Biomedical Ethics (4 ed), Oxford University Press, New York

Becker L. C. [1992], "Places for Pluralism”, Ethics, vol. 102, pp. 707-719

Boblio R. (1987), Which Socialism, Polity Press, Londres

Boudon R. [1986], L'idéologie ou l'origine des idées reçues, Fayard, Paris

Bowie N. [1994], "A Kantian theory of Capitalism", presented at the 1994 Ruffin Lectures, The Dearden School, University of Virginia, Charlotteville, Virginia

Bucholz R.A. et al (1994), Management Response in Public Issues, Prentice Hall

Brenner S. N., Cochran P. [1991], "The stakeholder theory of the Firm: Implications for Business and

Society theory and Research", Annual Meeting of the International Association of Business and Society, Sundance, Utah

Brenner S. N., Molander E. A. [1977], "Is the Ethics of Business Changing?", Harvard Business Review, vol. $58, \mathrm{n}^{\circ} 1$, pp. 5465

Caroll A. B. [1989], Business and Society: Ethics and Stakeholder Management, O.H.: South Western, Cincinatti

Clarkson M. B. [1991], "Defining, Evaluating, and Managing Corporate Social Performance: A Stakeholder Management Model", in J.E. Post (Ed.), Research in Corporate Social Performance and Policy, J.A.I. Press, Greenwich, Connecticut, pp. 331-358

Clarkson M. B. [1995], "A Stakeholder Framework for Analysing and Evaluating Corporate Social

Performance", Academy of Management Review, vol. 20, n ${ }^{\circ}$, pp. 92-117

Coase R. H. [1937], "The Nature of the Firm", Economica, vol. 16, pp. 331-351

Cochran P. L., Wood R. A. [1984], "Corporate Social Responsibility and Financial Performance", Academy of Management Journal, vol. 27, $\mathrm{n}^{\circ} 1$, pp. 42-56

Cornel B., Shapiro A. C. [1987], "Corporate Stakeholders and Corporate Finance", Financial Management, vol. 16, pp. 5-14

Crozier M., Friedberg E. [1977], L'acteur et le système, Seuil, Paris

Donaldson T., Preston L. E. [1995], "The stakeholder theory of the Corporation: Concepts, Evidence, and Implications", Academy of Management Review, vol. 20, $\mathrm{n}^{\circ} 1$, pp. 65-91

Evan W., Freeman R. E. [1983], "A stakeholder theory of the Modern Corporation: Kantian Capitalism", in T. Beauchamp \& N. Bowie (Eds), Ethical theory and Business, Englewood Cliffs, Prentice Hall, New Jersey, pp. 75-93

Franklin B. (1748), Advices to a Young Tradesman, Editions Sparks, Boston (1840)

Freeman E. R. [1984], Strategic Management: A Stakeholder Approach, Pitman, Boston

Freeman E. R., Evan W. M. [1990], 'Corporate Governance: A Stakeholder Interpretation”, The Journal of Behavioural Economics, vol. 19, n 4 , pp. 337-359

Freeman E. R. [1994], "The Politics of stakeholder theory: Some Future Directions", Business Ethics Quarterly, vol. 4, n 4, pp. 409-421

Freeman E. R. [1999], "Divergent stakeholder theory", Academy of Management Review, vol. 24, n², pp. 233-236

Friedman M. (1970), "The Social Responsibility of Business is to Increase its Profits", The New York Times Magazine, September 13

Amy Gutmann A., Thompson D. (1996), Democracy and Disagreement, Harvard University Press

Hall S., Jefferson T. (eds) (1975), Resistance through Rituals, Routledge, London

Hall S., Jacques M. (eds) (1990), New Times: The Changing Face of Politics in the 1990's, Hutchinson, London 
Halal W.E. [1990], "The Management: Business and Social Institutions in the Information Age", Business in the Contemporary World, vol. 2, n'2, pp. 41-54

Hill C. W. L., Jones T. H. [1992], "Stakeholder - Agency theory", Journal of management Studies, vol. 29, n², pp. 131-153

Hoggart R. (1973), Speaking to each other, Pelican Books, London

Hutton J. (1999), The Stakeholders Society, Blackwell, London

Jensen M. C. (2000), "Value Maximisation and the Corporate Objective Function", in Beer M., Nohria N.,

Breaking the Code of Change, Harvard Business School Press, Boston, Massachussets, USA

Jensen M. C. (2002), "Value Maximisation, stakeholder theory, and the Corporate Objective Function", Business Ethics Quarterly, vol. 12, Issue 2, pp. 235-256

Jones T. M. [1995], "Instrumental stakeholder theory: A Synthesis of Ethics and Economics, Academy of Management Review, vol. 20, n², pp. 404-437

Jones T. M., Wicks A. C. [1999], "Convergent stakeholder theory", Academy of Management Review, vol. 24, n², pp. 206-221

R.\& Kahn R.L. [1966, 1978], The Social Psychology of Organisations, John Wiley and Sons, New York Konrad A. [1982], "Business Managers and Moral Sanctuary", Journal of Business Ethics, vol. 1, pp. 195200

Kreiner P., Bambir A. [1991], "Influence and Information in Organisation - Stakeholder Relationships", in J.E. Post (Ed.), Research in Corporate Social performance and Policy, J.A.I. Press, Greenwich, Connecticut, pp. 3-36

Lépineux F. [2003], "Dans quelle mesure une entreprise peut-elle être responsable à l'égard de la cohésion sociale ?", Thèse de Doctorat en Sciences de Gestion, C.N.A.M., Paris

MacIntyre A. (1984), After Virtue, Duckworth, Londres, Après la vertu, P.U.F., Paris, 1997

McGuire J. B., Sundgren A., Scheeweis T. [1988], "Corporate Social Responsibility and Firm Financial Performance", Academy of Management Journal, vol. 31, pp. 354-372

Mercier S. [1999], L'éthique dans les entreprises, Editions La Découverte, collection "Repères", Paris

Mintzberg H. [1987], Structure et dynamique des organisations, Editions d'Organisation, Paris

Mitchell R. K., Agle B. R., Wood D. J. [1997], "Toward a theory of Stakeholders Identification and

Salience: Defining the Principles of who and what really Counts", Academy of Management Review, vol. 22, n०2, pp. 833-886

Mouffe C. (1994), Le politique et ses enjeux - pour une démocratie plurielle, La Découverte / M.A.U.S.S., Paris

Pelle Culpin C. I. [1998], "Du paradoxe de la diffusion d'informations environnementales par les entreprises européennes", Thèse de Doctorat, Université de Paris IX Dauphine

Pesqueux Y. (2001), "Des histoires à l'histoire dans la formation de la stratégie ", Le management stratégique en représentation, DRISSE (Ed), Ellipses

Pesqueux Y. [2002], Organisations : modèles et représentations, P.U.F., Paris

Phillips R., Freeman R. E., Wicks A. C. (2003), "What stakeholder theory is not?", Business Ethics Quarterly, vol. 13, n ${ }^{\circ} 4$

Preston L. E., Shapienza H. J. [1990], "Stakeholder Management and Corporate Performance, Journal of Behavioural Economics, vol. 19, pp. 361-375

Preston L. E., Sapienza H. J., Miller R. D. [1991], "Stakeholders, Shareholders, managers: Who Gains What from Corporate Performance?", in A. Etzioni \& P. R. Lawrence (Eds), Socio-Economics: Toward a New Synthesis, M.E. Sharp, Armonk, New York, pp. 149-165

Sandel M. (1982), Liberalism and the Limits of Justice, Cambridge University Press

Quinn D., Jones T. [1995], "An Agent Morality View of Business Policy", Academy of Management

Review, vol. 20, $\mathrm{n}^{\circ} 1$, pp. 22-42

Rawls J. [1987], Théorie de la justice, Seuil, Paris

Ricœur P. (1997), L'idéologie et l'utopie, Seuil, Collection “ la couleur des idées ”, Paris

Tocqueville A. de (1835), De la démocratie en Amérique, Garnier Flammarion, Paris, n 353-354 
Ullmann A. A. [1985], "Data in Search of a theory: A Critical Examination of the Relationships among Social Performance, Social Disclosure, and Economic Performance of U.S. Firms", Academy of Management Review, vol. 10, ${ }^{\circ} 3$, pp. 540-557

Waddock S.A., Boyle M.E. [1995], "The Dynamic of Change in Corporate Community Relations", California Management Review, vol. 37, n4, pp. 125-140

Walzer M. (1983), Spheres of Justice - A Defense of Pluralism and Equality, Basic Books, New York

Walzer M. (1998), Traité sur la tolérance, Gallimard, collection NRF essais, Paris 1998

Weaver G. R., Trevino L. K. [1994], "normative and empirical Business Ethics", Business Ethics Quarterly, vol. 4, pp. 129-144

Weaver G. R., Trevino L. K., Cochran P. L. [1999], "In Press Corporate Ethics Programs as Control Systems: Influences of Executive Commitment and Environment Factors", Academy of Management Journal, vol. 24, $\mathrm{n}^{\circ} 2$

Weber M. (1990), L'éthique protestante et l'esprit du capitalisme, Presses Pocket, collection "Agora" n 8, Paris, 1990

Williamson O. E. [1985], The Economic Institutions of Capitalism, Free Press, New York

Willis P. (1977), Learning to Labour. How Working-Class Kids get Working-Class Jobs, Oxford University 